\title{
ANALYSIS OF VIROME BY HIGH-THROUGHPUT SEQUENCING REVEALED MULTIPLE INFECTION AND INTRA-VIRUS DIVERSITY IN A SINGLE GRAPEVINE PLANT
}

\author{
Miroslav GLASA ${ }^{1 *}$, Lukáš PREDAJŇA ${ }^{1}$, Nina SIHELSKÁ ${ }^{2}$, Katarína ŠOLTYS² ${ }^{2}$ Ana-Belén RUIZ-GARCÍA ${ }^{3}$ \\ ${ }^{1}$ Biomedical Research Centre of the Slovak Academy of Sciences, Institute of Virology, Bratislava, Slovak Republic \\ ${ }^{2}$ Comenius University in Bratislava, Bratislava, Slovak Republic \\ ${ }^{3}$ Instituto Valenciano de Investigaciones Agrarias, Center of Plant Protection and Biotechnology, Moncada, Spain
}

The ribosomal-depleted total RNA from white-berry grapevine (Vitis vinifera, SK933) plant showing severe chlorosis and downrolling of leaves was used for the high-throughput sequencing (HTS) analysis in order to unravel the potential contribution of the viral pathogens to the symptomatology observed. The combination of de novo assembly and mapping of ca. 1.1 millions of HTS reads enabled to identify and characterise a complex viral/viroid infection involving Grapevine leafroll-associated virus-2 (GLRaV-2), Grapevine leafroll-associated virus-3 (GLRaV-3), Grapevine rupestris stem pitting-associated virus (GRSPaV), Grapevine rupestris vein feathering virus (GRVFV), Grapevine Syrah virus-1 (GSyV-1) and Hop stunt viroid (HSVd). The determined nearly complete genomes of GLRaV-2 SK933 showed its high genetic divergence from previously characterised isolates. In case of GRSPaV, two variants representing different evolutionary lineages have been identified in the plant. The results further pinpoint the complexity of grapevine viral diseases and show that mixed virus infection of grapevine is rather a rule than an exception.

Keywords: Vitis vinifera, virus, diversity, next generation sequencing

Grapevine (Vitis vinifera L.) is one of the most ancient and widely grown crops in the world, used for the production of fresh fruits, wines, juices, and other by-products. On the other hand, grapevine has turned out to be the cultivated plant hosting the highest number of viral pathogens (Martelli, 2017), many of them being associated with economically important diseases, such as leafroll, rugose wood complex, leaf degeneration and flecks (Basso, Fajardo and Saldarelli, 2017).

The study of genetic diversity and the evolutionary mechanisms shaping the virus variability is important to understand virus epidemiology and emergence and is a prerequisite to design effective diagnostic tools and implement effective disease management measures.

Mutations, connected with positive and negative selection and recombination of genome are the main evolutionary forces driving the genetic diversity of viral populations. These processes, leading to the dynamic genetic structure of virus populations, have a significant role in the epidemiology of the grapevine viruses as they constitute the basis of their adaptation to the environment (Almeida et al., 2013; Maliogka et al., 2015).

A rapid, specific and effective diagnose integrated to the certification schemes is one of the most important tools to control grapevine viruses (Zherdev et al., 2018). However, the effectiveness of such measures can be negatively affected by a high virus genetic variability and occurrence of divergent variants escaping the detection (Glasa et al., 2015).

Knowledge on the occurrence of grapevine viruses in Slovakia and their characterisation remains insufficient. First studies aimed to characterize the grapevine viruses spread in Slovakia were based on standard genomic tools (Glasa, Predajňa and Komínek, 2011; Glasa and Predajňa, 2012; Predajňa et al., 2013; Predajňa and Glasa, 2016), possibly not detecting the whole viral complexity present in the grapevines. The recent developments of high-throughput sequencing (HTS) technologies and bioinformatics have drastically improved identification and characterisation of viral pathogens without prior knowledge of their primary structure (Maliogka et al., 2018). HTS has mostly had an impact so far through the identification and characterisation of new grapevine virus species, the study of diseases of unknown aetiology, with the identification of candidate disease-associated agents and, for some viruses, a large improvement of existing diagnostic assays (Saldarelli et al., 2017). In recent years, HTS has provided the possibility to identify and characterize several common or emerging grapevine viruses in Slovakia (Glasa et al., 2014; 2015; 2017; 2018).

The aim of the present work was the unbiased identification and characterization of complete virome present in a grapevine plant showing severe virus-like symptoms.

Contact address: Miroslav Glasa, Biomedical Research Centre of the Slovak Academy of Sciences, Institute of Virology, Dúbravská cesta 9, 84505 Bratislava, Slovak Republic, tel.: +421 2593024 47, e-mail: Miroslav.Glasa@savba.sk 


\section{Material and method}

An approximately 30-year old white-berry grapevine of unknown origin grown in the vineyard in Pezinok (western Slovakia, GPS coordinates: $48^{\circ} 18^{\prime} 09.8^{\prime \prime} \mathrm{N} 17^{\circ} 15^{\prime} 40.7^{\prime \prime} \mathrm{E}$ ) and showing pronounced chlorosis and leafroll, was selected for the HTS analysis (further referred as the SK933 sample).

Total RNAs from fully developed leaves collected in August 2017 were extracted using the Spectrum Plant Total RNA Kit (Sigma Aldrich, St. Louis, MO, USA) and ribosomal RNA was removed using the Ribo-Zero rRNA Removal Kit (Illumina, San Diego, USA). The sample of ribosomaldepleted total RNA was used for double stranded cDNA synthesis using the SuperScript II kit (Thermo Fisher Scientific, Waltham, USA). The cDNA was then columnpurified with the DNA Clean \& Concentrator ${ }^{\mathrm{TM}}-5$ - DNA kit (Zymo Research, Irvine, USA) and quantified with the Qubit 2.0 Fluorometer (Thermo Fisher Scientific, Waltham, USA). Subsequently, the sample was processed with the transposon-based chemistry library preparation kit (Nextera XT, Illumina, San Diego, USA). Low-cycle PCR and mutual indexing of the fragments was carried out. Fragments were purified with $1.8 \times$ AMPure XP beads (BeckmanCoulter, USA) without size selection. The fragment size structure of the DNA library was assessed using the Agilent 2100 Bioanalyzer (Agilent Technologies, Santa Clara, USA). The equimolar pool of 4nM DNA libraries was denatured, diluted to $13 \mathrm{pM}$ and sequenced (200-bp paired-end sequencing) on the Illumina MiSeq platform (Illumina, San Diego, CA, USA).

High-quality trimmed reads were used for de novo assembly and contigs aligned to the viral genomes database (Brister et al., 2015) or to the genome of V. vinifera (Velasco et al., 2007) using CLC Genomics Workbench 7.5 and Geneious v.8.1.9 softwares. Alternatively, the reads were mapped against the selected full-length sequences of viruses identified in the previous step to map the de novo assembled contigs (retrieved from www.ncbi.nlm. nih.gov).

Phylogenetic analyses and comparisons were performed using the MEGA v.7 (Kumar, Stecher and Tamur, 2016) and DnaSP v.6 (Rozas et al., 2017) softwares.
The nucleotide sequences reported in this paper have been deposited in the GenBank database under accession numbers listed in Table 1.

\section{Results and discussion}

The SK933 grapevine plant, exhibiting pronounced chlorosis and downrolling of leaves, was selected for the HTS analysis in order to unravel the potential contribution of the viral pathogens to the symptomatology observed.

The de novo assembly of about 1.1 million of high-quality HTS reads (average length of $164.9 \mathrm{bp}$ ) from this grapevine sample produced more than 20000 contigs longer than 280 bp (of which 19851 contigs mapped to the $V$. vinifera host). Several of the other generated contigs were of viral/viroid origin and led to the identification of a complex co-infection of the SK933 plant by Grapevine leafroll-associated virus-2 (GLRaV-2), Grapevine leafroll-associated virus-3 (GLRaV-3), Grapevine rupestris stem pitting-associated virus (GRSPaV), Grapevine rupestris vein feathering virus (GRVFV), Grapevine Syrah virus-1 (GSyV-1) and Hop stunt viroid (HSVd).

Combination of de novo assembly and subsequent mapping of NGS reads against genomes of representative isolates of above-mentioned pathogens retrieved from Genbank enabled to obtain nearly complete genomes for GLRaV-2, GLRaV3, GRSPaV and HSVd, as well as partial sequences of GRVFV and GSyV-1. Interestingly, in case of GRSPaV, two genetically different variants could be assembled from the sequence data.

Multiple alignment of the full-length nucleotide sequence of SK933 GLRaV-2 revealed only 72.1 to $85 \%$ identity of Slovak isolate with available GLRaV-2 genomes from different parts of the world. Phylogenetic analysis further confirmed the molecular divergence of SK933 GLRaV-2, clustering in a separate branch, most closely related to the Canadian and Chinese isolates (Fig. 1).

On the contrary, nearly full-length SK933 GLRaV-3 sequence showed low divergence, as compared to other GLRaV-3 isolates, and showed the close phylogenetic relationship with GLRaV-3 isolates from North and South American continent (Fig 2).

Table 1 List of viral/viroid pathogens identified in the SK933 from the HTS dataset (1 163370 high quality reads, mean length $164,9 \mathrm{bp}$ ) and their characteristics

\begin{tabular}{|c|c|c|c|c|c|c|}
\hline $\begin{array}{l}\text { Virus } \\
\text { acronym }\end{array}$ & Virus name & Genus & Family & $\begin{array}{l}\text { NGS reads mapped } \\
\text { to the reference }\end{array}$ & $\begin{array}{l}\text { Genome } \\
\text { coverage }\end{array}$ & $\begin{array}{c}\text { Genbank accession } \\
\text { numbers }\end{array}$ \\
\hline GLRaV-2 & $\begin{array}{c}\text { Grapevine leafroll-associated } \\
\text { virus-2 }\end{array}$ & Ampelovirus & Closteroviridae & 16,902 & $100 \%$ & MN548394 \\
\hline GLRaV-3 & $\begin{array}{l}\text { Grapevine leafroll-associated } \\
\text { virus-3 }\end{array}$ & Closterovirus & Closteroviridae & 7,435 & $99.2 \%$ & MN548393 \\
\hline GRSPaV & $\begin{array}{l}\text { Grapevine rupestris stem pitting- } \\
\text { associated virus }\end{array}$ & Foveavirus, & Betaflexiviridae & $\begin{array}{c}1,335 \\
860\end{array}$ & $\begin{array}{l}93.3 \% \\
49.3 \%\end{array}$ & $\begin{array}{l}\text { MN548395a } \\
\text { MN548396b }\end{array}$ \\
\hline GRVFV & $\begin{array}{l}\text { Grapevine rupestris vein } \\
\text { feathering virus }\end{array}$ & Marafivirus & Tymoviridae & 288 & $67.4 \%$ & not submitted \\
\hline GSyV-1 & Grapevine Syrah virus-1 & Marafivirus & Tymoviridae & 432 & $85.7 \%$ & not submitted \\
\hline HSVd & Hop stunt viroid & Hostuviroid & Pospiviroidae & 63 & $100 \%$ & MN548397 \\
\hline
\end{tabular}

a) GRSPaV group 2a variant, b)group 3 variant 


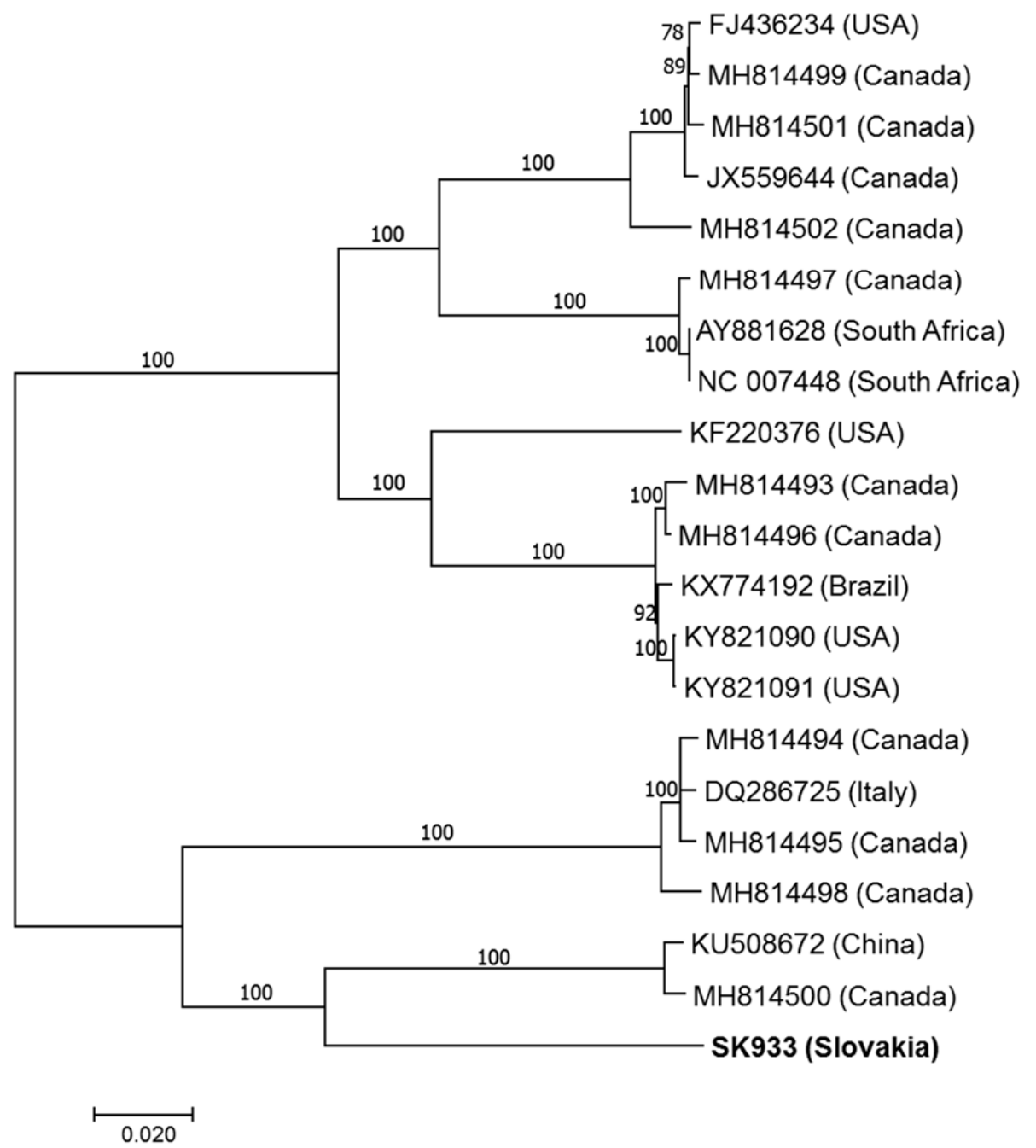

Figure 1 Phylogenetic tree generated on complete nucleotide genome sequences of GLRaV-2 isolates. Isolates are identified by their GenBank accession number and country of their origin. The Slovak isolate sequenced in the present study is highlighted in bold. The scale bar indicates a genetic distance of 0.02 . Bootstrap values higher than $70 \%(1,000$ bootstrap resamplings) are indicated

The determined full-length HSVd genome consisted of $297 \mathrm{nt}$, having the same length and 100\% identity with HSVd isolates from Brazil (MF774869, MF774870, MF774873) and China (AB219944).

Two molecularly distinct variants of GRSPaV identified in the grapevine plant differed mutually by $26.8 \%$ at the nucleotide level and belonged, respectively, to the phylogenetic groups 2 a and 3 (Glasa et al., 2017) and thus to different evolutionary lineages.

In case of two other viruses identified (GRVFV and GSyV-1), their genomes could not be completed because of the lower coverage of the full-length reference sequences (Table 1). However, based on the partial sequence data, both exhibited a close relationship to the respective isolates previously reported from Slovakia (Glasa et al., 2015; Glasa et al., 2019).

HTS-based characterisation of divergent GLRaV-2 variant highlights the need for a continual assessment of the grapevine virus molecular variability (also at the regional level) as a prerequisite to understand the globality of virus variability. Also, the identification of several viruses/ viroids and, moreover, different variants of the same virus in a single plant, further emphasizes the complex and heterogeneous nature of grapevine viral diseases (Komínek, Glasa and Komínková, 2009; Glasa et al., 2017), indicating that a complex viral infection of grapevine is rather a rule than an exception.

The close phylogenetic clustering of geographically different isolates from different unrelated countries, or even continents (as observed e.g. for GLRaV-2, GLRaV-3 and HSVd) suggests a long term uncontrolled spread of these pathogens and their widespread dissemination, probably through the exchange and trade of infected propagation material.

The aetiology of the disease observed in the SK933 plant cannot be elucidated properly, as the coexistence of several virus/viroid agents in a single grapevine plant (possibly acting in synergy or antagonism) challenges the establishment of links between the symptoms observed and the presence of a given infectious agent. 


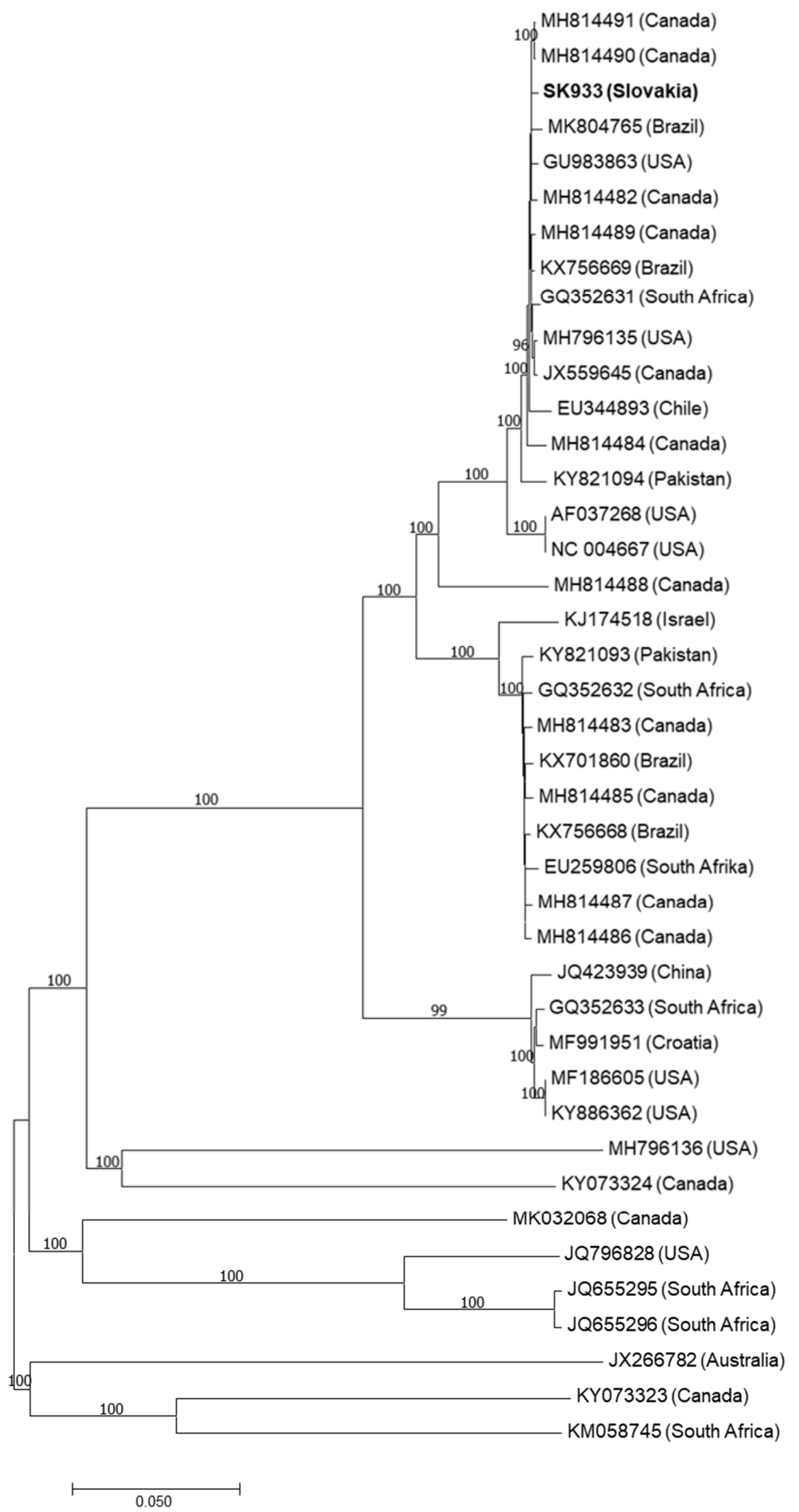

Figure 2 Neighbour-joining phylogenetic tree generated from nearly complete GLRaV-3 sequences. The corresponding sequences of previously characterized isolates are identified by their accession numbers and geographical location. Only bootstrap values $\geq 70 \%$ (1,000 bootstrap resamplings) are indicated. The scale bar indicates a genetic distance of 0.05 
HTS technologies have been confirmed to be a powerful diagnostic tool allowing for an exhaustive description of viral species present in many grapevines (Saldarelli et al., 2017). Further information about viromes of grapevines from different production areas or agroecological contexts should help to improve the control and analyses of the different interactions involved in the ecology and pathogenicity of viral agents. This is particularly important for novel viral agents, recently identified by HTS. Moreover, in case of already known viruses, gaining access to the unbiased viral diversity might allow to validate and further improve existing detection assays by fine tuning the detection, e.g. through designing updated primers in order to improve their polyvalence and/or specificity.

\section{Conclusion}

In this work, ribosomal-depleted total RNA isolated from leaves of symptomatic grapevine plant grown in a vineyard in western Slovakia was subjected to HTS. Analysis of obtained sequence dataset revealed the presence of complex viral/ viroid infection involving members of the Closteroviridae, Betaflexiviridae, Tymoviridae and Pospiviroidae families. Moreover, in case of GRSPaV, two genetically distinct variants were identified. Together, these results further highlight the complex and heterogeneous nature of grapevine virome, hampering a clear-cut establishment of links between the symptoms observed and the respective infectious agent(s) present in the plant.

\section{Acknowledgements}

This work was supported by the grant VEGA 2/0030/20 from the Scientific Grant Agency of the Ministry of Education and Slovak Academy of Sciences.

\section{References}

ALMEIDA, R.P. - DAANE, K.M. - BELL, V.A. - BLAISDELL, G.K. COOPER, M.L. - HERRBACH, E. - PIETERSEN, G. 2013. Ecology and management of grapevine leafroll disease. In Frontiers in Microbiology, vol. 4, 2013, pp. 94, doi:10.3389/fmicb.2013.00094.

BASSO, M.S. - FAJARDO, T.V.M., - SALDARELLI, P. 2017. Grapevine virus diseases: economic impact and current advances in viral prospection and management. In Revista Brasileira de Fruticultura, vol. 39, 2017, e-411, doi: 10.1590/0100-29452017411

BRISTER, J.R. - AKO-ADJEI, D. - BAO, Y. - BLINKOVA, O. 2015. NCBI Viral Genomes Resource. In Nucleic Acids Research, vol. 43, 2015, pp. 571-577. doi: 10.1093/nar/gku1207

GLASA, M. - PREDAJŇA, L. 2012. Partial sequence analysis of a grapevine leafroll-associated virus 3 isolate from Slovakia. In Journal of Plant Pathology, vol. 94, 2012, pp. 675-679.

GLASA, M. - PREDAJŇA, L. - KOMÍNEK, P. - NAGYOVÁ, A. CANDRESSE, T. - OLMOS, A. 2014. Molecular characterization of divergent grapevine Pinot gris virus isolates and their detection in Slovak and Czech grapevines. In Archives of Virology, vol. 159, 2014, pp. 2103-2107.

GLASA, M. - PREDAJŇA, L. - KOMÍNEK, P. 2011. Grapevine fleck virus isolates split into two distinct molecular groups. In Journal of Phytopathology, vol. 159, 2011, pp. 805-807.

GLASA, M. - PREDAJŇA, L. - SIHELSKÁ, N. - ŠOLTYS, K. - RUIZGARCÍA, A.B. - OLMOS, A. - WETZEL, T. - SABANADZOVIC, S. 2018. Grapevine virus $T$ is relatively widespread in Slovakia and Czech
Republic and genetically diverse. In Virus Genes, vol. 54, 2018, pp. 737-741.

GLASA, M. - PREDAJŇA, L. - ŠOLTYS, K. - SABANADZOVIC, S. OLMOS, A. 2015. Detection and molecular characterisation of Grapevine Syrah virus-1 isolates from Central Europe. In Virus Genes, vol. 51, 2015, pp. 112-121.

GLASA, M. - PREDAJŇA, L. - ŠOLTYS, K. - SIHELSKÁ, N. NAGYOVÁ, A. - WETZEL, T. - SABANADZOVIC, S. 2017. Analysis of Grapevine rupestris stem pitting-associated virus in Slovakia reveals differences in intra-host population diversity and naturally occurring recombination events. In The Plant Pathology Journal, vol. 33, 2017, pp. 34-42.

GLASA, M. - PREDAJŇA, L. - WETZEL, T. - ŠOLTYS, K. SABANADZOVIC, S. 2019. First report of Grapevine rupestris vein feathering virus in grapevine in Slovakia. In Plant Disease, vol. 103, 2019, pp. 170.

KOMÍNEK, P. - GLASA, M. - KOMÍNKOVÁ, M. 2009. Analysis of multiple virus-infected grapevine plant reveals persistence but uneven virus distribution. In Acta Virologica, vol. 53, 2009, pp. 281-285.

KUMAR, S. - STECHER, G. - TAMURA, K. 2016. MEGA7: Molecular Evolutionary Genetics Analysis Version 7.0 for Bigger Datasets. In Molecular Biology and Evolution, vol. 33, 2016, pp. 1870-1874.

MALIOGKA, V.I. - MARTELLI, G.P. - FUCHS, M. - KATIS, N.I. 2015. Control of viruses infecting grapevine. In Advances in Virus Research, vol. 91, 2015, pp. 175-227.

MALIOGKA, V.I. - MINAFRA, A. - SALDARELLI, P. - RUIZ-GARCÍA, A.B. - GLASA, M. - KATIS, N. - OLMOS, A. 2018. Recent advances on detection and characterization of fruit tree viruses using highthroughput sequencing technologies. In Viruses, vol. 10, pii: E436, doi: 10.3390/v10080436

MARTELLI, G.P. 2017. An overview on grapevine viruses, viroids, and the diseases they cause. In Grapevine Viruses: Molecular Biology, Diagnostics and Management (Meng, B. - Martelli, G.P. - Golino, D.A. - Fuchs, M. eds.)- Springer International Publishing, 2017, pp. 31-46. doi: 10.1007/978-3-319-57706-7_2

PREDAJŇA, L. - GAŽIOVÁ, A. - HOLOVIČOVÁ, E. - GLASA, M. 2013. Analysis of a short genomic region of Grapevine leafroll-associated virus 1 (GLRaV-1) reveals the presence of two different molecular groups of isolates in Slovakia. In Acta Virologica, vol. 57, 2013, pp. 353-356.

PREDAJŇA, L. - GLASA, M. 2016. Partial sequence analysis of geographically close Grapevine virus $A$ isolates reveals their high regional variability and an intra-isolate heterogeneity. In Journal of Phytopathology, vol. 164, 2016, pp. 427-431.

ROZAS, J. - FERRER-MATA, A. - SÁNCHEZ-DELBARRIO, J.C. GUIRAO-RICO, S. - LIBRADO, P. - RAMOS-ONSINS, S.E. - SÁNCHEZGRACIA, A. 2017. DnaSP 6: DNA Sequence Polymorphism Analysis of large data sets. In Molecular Biology and Evolution, vol. 34, 2017, pp. 3299-3302.

SALDARELLI, P. - GIAMPETRUZZI, A - MAREE, H - AL RWAHNIH, M. 2017. High-Throughput Sequencing: Advantages beyond virus identification. In Grapevine Viruses: Molecular Biology, Diagnostics and Management (Meng, B. - Martelli, G.P. - Golino, D.A. - Fuchs, M. eds.), Springer International Publishing, 2017, pp. 625-642, doi: 10.1007/978-3-319-57706-7_30

VELASCO, R. - ZHARKIKH, A. - TROGGIO, M. - CARTWRIGHT, D.A. CESTARO, A. et al. 2007. A high quality draft consensus sequence of the genome of a heterozygous grapevine variety. In PLoS One, vol. 2, 2007, E1326. doi: 10.1371/journal.pone.0001326

ZHERDEV, A.V. - VINOGRADOVA, S.V. - BYZOVA, N.A. POROTIKOVA, E.V. - KAMIONSKAYA, A.M. - DZANTIEV, B.B. 2018. Methods for the diagnosis of grapevine viral infections: A review. In Agriculture, vol. 8, 2018, pp. 195; doi: 10.3390/agriculture8120195. 